\title{
Mitokondrial miyopati ile seyreden SANDO sendromunda rehabilitasyon
}

\author{
Rehabilitation of SANDO syndrome with mitochondrial myopathy
}

Alev Atıgan, Füsun Şahin

\section{Özet}

Mitokondrial miyopatiler, mitokondrial DNA (mtDNA) mutasyonu sonucu oksidatif fosforilasyonun bozulduğu ve dolayısıyla multisistemik semptom ve bulguların görüldüğü hastalık grubudur. Bu hastaların rehabilitasyonunda uygulanması gereken egzersiz şiddeti yeni çalışılan bir konu olup halen netliğe kavuşturulamamıştır. Bu olgu sunumunda yürüme güçlüğü ve kas güçsüzlüğü ile kliniğimize başvuran, mitekondrial miyopatilerin bir grubu olan SANDO sendromu tanısı mevcut olan bir bayan hasta eşliğinde mitokondrial miyopatilerde rehabilitasyon özellikleri tartışılacaktır.

Anahtar kelimeler: SANDO sendromu, mitokondrial miyopati, egzersiz.

Atıgan A, Şahin F. Mitokondrial miyopati ile seyreden SANDO sendromunda rehabilitasyon. Pam Tıp Derg 2020;13:215-218.

\begin{abstract}
Mitochondrial myopathies are a group of diseases where oxidative phosphorylation is impaired as a result of mitochondrial DNA (mtDNA) mutation and thus multisystemic symptoms and findings are seen. The exercise intensity of these patients cannot be clarified. In this case report, the rehabilitation features of mitochondrial myopathies will be discussed by presented a female patient who has walking difficulty and muscle weakness with the diagnosis of SANDO syndrome which is a group of mitochondrial myopathies.
\end{abstract}

Key words: SANDO syndrome, mitochondrial myopathies, exercise.

Atıgan A, Şahin F. Rehabilitation of SANDO syndrome with mitochondrial myopathy. Pam Med J 2020;13:215218.

\section{Giriş}

Metabolik miyopatiler, glikojen depo hastalıkları, lipid depo hastalıkları ve mitokondrial miyopatiler olmak üzere üç gruba ayrılmaktadır [1]. Mitokondrial miyopatiler, mitokondrial DNA (mtDNA) mutasyonu sonucu oksidatif fosforilasyonun bozulduğu ve dolayısıyla multisistemik semptom ve bulguların görüldüğü hastalık grubudur [2]. Yüksek enerji ihtiyacı olan, kas ve santral sinir sistemi gibi dokular daha çok etkilenmektedir [3]. İyi tanımlanmış pek çok mitokondrial sendrom olsa da mitokondrial hastalıkların henüz kabul edilmiş bir sınıflaması yoktur. SANDO sendromu (Sensoryel Ataksik Nöropati, Dizartri, Oftalmoparezi), polimeraz-c1 (POLG1) mutasyonu sonucu kas ve periferik sinirlerdeki mtDNA delesyonlarının neden olduğu, otozomal dominant veya resesif geçişli, nadir görülen ve erişkin başlangıçlı bir mitokondrial miyopati sendromudur [4]. Yürüyüş bozukluğu, pitoz, oftalmopleji, ataksi, dizartri, nöbet, işitme kaybı, Romberg bulgusu, derin tendon reflekslerinde azalma en yaygın klinik bulgulardır [4].

Kas güçsüzlüğü olan hastalarda klasik yaklaşım kuvvetlendirme egzersizleridir. Ancak miyopati hastalarında kuvvetlendirme ile aşırı kullanım olduğunda kas lifi dejenerasyonu söz konusu olabilir. Kuvvetlendirme egzersizleri şiddetvesüreolaraksubmaksimaldüzeydeolmalı ve aşırı kullanıma bağlı kuvvetsizlik gelişmesi önlenmelidir [1]. Ancak mitokondrial miyopatili hastaların rehabilitasyonunda uygulanması gereken egzersiz şiddeti yeni çalışılan bir konu olup halen netliğe kavuşturulamamıştır. Bu olgu sunumunda nadir görülen SANDO sendromlu bir olgu tanıtılacak ve mitokondrial miyopatide rehabilitasyon yaklaşımları güncel bilgiler ışığında tartışılacaktır.

Alev Atıgan, Uzm. Dr. Çivril Şehit Hilmi Öz Devlet Hastanesi, Fiziksel Tıp ve Rehabilitasyon Kliniği, UŞAK, e-posta: alevozaydin89@hotmail.com (orcid. org/0000-0003-4082-3055) (Sorumlu Yazar)

Füsun Şahin, Prof. Dr. Pamukkale Üniversitesi, Fiziksel Tıp ve Rehabilitasyon Anabilim Dalı, DENiZLi, e-posta: drfusunsahin@yahoo.com (orcid. org/0000-0001-5231-7702) 


\section{Olgu sunumu}

Yürüme güçlüğü ve kas güçsüzlüğü şikayeti ile kliniğimize başvuran 48 yaşında kadın hasta rehabilitasyon amacıyla yatırıldı. Öyküde 12 yıl önce yürüme güçlüğü, dengesizlik/ düşme şikayetleri başlayan hastanın birkaç kere nöroloji kliniğine başvurduğu ancak o dönemde tanı konulamadığı öğrenildi. Zamanla yürüme güçlüğünün artması nedeniyle tekrar başvurduğu bir üniversite hastanesi nöroloji kliniğinde yapılan kas biyopsisi neticesinde hastada miyopati tespit edildiği ve yapılan genetik inceleme ile de SANDO sendromu tanısı konduğu öğrenildi. Hastaya bu merkezde bir yıl boyunca medikal tedavi verildiği ancak aşırı iştahsizlik, kilo kaybı gibi yan etkiler nedeniyle medikal tedavi sonlandııılığı öğrenildi. Hasta zamanla göz kapağında düşme şikayetinin olduğu ve göremeyecek kadar gözleri düştüğü için 2016 yılında göz kapağı ameliyatı geçirdiğini belirtti.

Özgeçmişinde, 2005 yılında kolesistektomi ameliyatı ve 2016 yılında göz kapağı operasyonu olan hastanın soygeçmişinde kardeşinde ve teyzesinde göz kapağı düşüklüğü ve yürüme güçlüğü olduğu ancak herhangi bir tanı konmadığı, annenin kolon kanseri nedeniyle ex olduğu öğrenildi.

Hastanın fizik muayenesinde; genel durumu iyi, bilinci açık, oryantasyon ve kooperasyon tamdı. Hastada dizartrik konuşma mevcuttu. Gastrointestinal, solunum ve kardiyovasküler muayene olağandı. Lokomotor sistem muayenesinde; üst ve alt ekstremite pasif eklem hareket açıklıkları tamdı. Hasta yürüteç ile kısa mesafe ambule idi. Kısa adımlarla ve fleksiyon postürde yürüyen hasta fonksiyonel ambulasyon sınıflamasına (FAS) göre evre 4 idi. Hastanın servikal ve lomber lordozu azalmış, torakal kifozu artmıştı. Kranial sinir muayenesi normaldi. Romberg bulgusu pozitifti. Yapılan manuel kas testi muayenesinde omuz kuşağı bilateral $3 / 5$, kalça kuşağı bilateral $3 / 5$, diz fleksiyonu bilateral $4 / 5$, diğer kas güçleri $5 / 5$ olarak saptandı.

Hastanın yatışındaki laboratuvar incelemelerinde; kreatinin kinaz (CK):79 $\mathrm{U} / \mathrm{L}(<170)$, laktat:30,78 mg/dl $[4,5,8,19]$, hemogram, rutin biyokimya ve idrar tahlilleri ise normal olarak saptandı. Hastanın aerobik kapasitesinin belirlemek amacıyla 10 metre yürüme testi yapıldı, 160 sn olarak saptandı.

Hastaya 20 seans boyunca, eklem hareket açıklığı, germe/güçlendirme egzersizlerinden oluşan fizik tedavi programı verildi. Egzersizler yorgunluk sınırında yapıldı. Yürüme, postür ve denge-koordinasyon egzersiz programı uygulandı. Hasta bisiklet ergometresini kullanamadığından bisiklette çalıştırılamadı, aerobik egzersiz için kol ergometresi ile çalıştıııldı.

Rehabilitasyon programı sonrası hastanın kas gücü değerlendirmesinde kalça ekstansiyonunun bilateral 4/5 olması dışında farklılık saptanmadı. Hastanın tripot ile ambulasyonu sağlandı ve daha uzun yürüme mesafesini tolere edebiliyordu. Hasta FAS'a göre evre 4 olarak taburcu edildi. Laboratuvar incelmesinde; CK:71U/L ve laktat:23,29 mg/dl olarak saptandı. Hasta rehabilitasyon sonrası 10 metre yürüme testini 90 sn'de tamamlayabildi.

\section{Tartışma}

Vücutta her sistem farklı miktarlarda mitokondri içerir ve her organ sisteminin yaş ve aktivite düzeyine bağlı olarak değişik oranlarda mitokondrial enerjiye intiyacı vardır. Normal ve mutant mtDNA'lar her dokuda farklı miktarlarda bir arada bulunabilir. Dokudaki mutant genomların oranı arttıkça ATP üretimi yetersizleşir ve bu durum dokuorgan disfonksiyonlarına neden olur. Beyin ve kas hücrelerinin enerji intiyacı daha fazladır. $\mathrm{Bu}$ organlarda düşük miktarda mutant mtDNA semptomatik olabilirken, daha yüksek oranda mutant mtDNA örneğin karaciğerde semptom vermeyebilir. Sonuçta, mutant ve normal genomlarin oranı, doku tipi, yaş, enerji intiyacı gibi faktörler fenotipi belirleyerek mitokondrial hastalık dediğimiz bir grup hastalığa neden olur [5].

Metabolik miyopatiler grubu içinde yer mitokondrial miyopatilerin tanımlı bir formu olan SANDO sendromunda yürüyüş bozukluğu, pitoz, oftalmopleji, ataksi, dizartri, nöbet, işitme kaybı, Romberg bulgusu, derin tendon reflekslerinde azalma en yaygın klinik bulgulardır $[1,4]$. Bizim hastamızda da yürüme güçlüğü, kas güçsüzlüğü, dizartri, işitme kaybı, pitoz, ataksi, pozitif Romberg bulgusu ve derin tendon reflekslerinde azalma mevcuttu. Ayrıca hastanın 
yutma güçlüğü olup buna bağlı yetersiz beslenme şikayeti mevcuttu. Mitokondrial miyopatili hastalarda değişen oranlarda kas güçüzlüğü bulunmaktadır. Serum CK düzeyleri olgumuzda da olduğu gibi çoğunlukla normal veya hafif yüksek olabilir. Serum laktat düzeyleri ise çoğu hastada yüksektir ancak normal saptanması mitokondrial miyopati tanısını dışlamamaktadır. Hastamızda da serum laktat düzeyleri normal aralıkta saptanmıştır [6]. Literatürde mitokondrial miyopatili hastalarda aerobik egzersiz ile serum laktat ve CK düzeylerini inceleyen çalışmalarda egzersiz ile CK düzeylerinin değişmediği, laktat düzeylerinin ise azaldığı gösterilmiştir. Laktat düzeyindeki azalma ise kas oksidasyon mekanizmasında iyileşme ile ilişkilendirilmiştir $[7,8]$.

Egzersiz şiddeti miyopatili hastalarda önemli bir konu olup mitokondrial miyopatili hastalarda egzersiz intoleransı en yaygın semptomlardan biridir. Sağlıklı insanların kolaylıkla yapabildiği günlük aktiviteler bu hastalarda yorgunluk, ağrı ve kramplara neden olabilmektedir. Pek çok çalışma, azalmış $\mathrm{VO}_{2}$ max nedeniyle mitokondrial bozukluğu olan hastaların egzersiz performansının kısıtlı olduğunu göstermiştir [9]. Bu eksiklik bozulmuş kas oksijen ekstraksiyonu nedeniyle görülmektedir. Ayrıca mitokondrial disfonksiyon anormal erken anaerobik yanıta da neden olmaktadır [10]. Egzersiz toleransı klasik olarak $\mathrm{VO}_{2}, \mathrm{VCO}_{2}$, anaerobik eşik ölçümlerini içeren ergospirometre kullanılarak saptanır [11]. Hastamız bisiklet ergometrisini tolere edemediği ve yürüme testi iyi olmadığı için ergospirometrik değerlendirmeye alınamadı. Değerlendirme 10 metre yürüme testi ile yapıldı ve egzersiz sırasında hastanın tolere edebileceği ölçüde kol ergometrisi ile aerobik egzersiz uygulandı. Ayrıca rehabilitasyon boyunca düşük dirençli therabant ile az tekrarlı güçlendirme egzersizleri verildi.

Literatürde mitokondrial miyopatili hastalarda egzersizin etkinliğini araştıran çalışmalar mevcuttur ancak SANDO sendromu ve egzersiz ile yapılan çalışmaya rastlanmadı. Mitokondrial miyopatili hastalarda kas aktivitesi boyunca sitozolik adenozin difosfat konsantrasyonunda değişikliklerle birliktemitokondrinin disfonksiyonu, anaerobik enerji yoluna bağımlılık ve proton akışında adaptif artış olduğu belirtilmektedir. Bu nedenle egzersiz tedavisi sonrası, mitokondrial fonksiyonda herhangi bir değişiklik olmaksızın iyileşme görüldüğü bildirilmektedir [12].
Mitokondrial disfonksiyonlu hastalarda dirençli-güçlendirme egzersizlerinin mutant mtDNA oranını azaltabileceği, hatta bu etkinin aerobik egzersizden daha fazla olabileceği söylenmektedir [13]. Güçlendirme egzersizi boyunca mutant mtDNA'yı azaltan satellit hücre aktivasyonu olmakta ve dolayısıyla respiratuar liflerde artış sağlanmaktadır [14].

Bir çalışmada, mitokondrial miyopatili hastaların aerobik egzersize cevabı nonmetabolik miyopatili hastalar ve sedanter sağlıklı kişilerle karşılaştırılmış ve mitokondrial miyopatili hastalarda aerobik kapasitede artışın diğer iki gruba göre daha fazla olduğu gösterilmiştir [15]. Jeppesen ve ark. [16] çalışmalarında, mitokondrial miyopatili hastalarda aerobik egzersizin kas morfolojisini, DNA mutasyonunu ve plazma $\mathrm{CK}$ düzeyini değiştirmeden $\mathrm{VO}_{2} \max$ düzeyinde iyileşme sağladığını göstermişlerdir. Mitokondrial miyopatili hastalara 8 hafta boyunca 30dk/gün, 3-4 seans/hafta uygulanan aerobik egzersizin aerobik kapasiteyi arttırdığı, istirahat kalp hızını azalttığı ve plazma laktat seviyesini azalttığı gözlemlenmiştir [17]. Bizim hastamızın da rehabilitasyon sonrası aerobik kapasitesi artmıştı. Hastamız rehabilitasyon öncesi 160 sn. süren 10 metre testini, rehabilitasyon sonrası 90 sn.'de tamamladı. Plazma bazal laktat ve CK enzim düzeylerinde ise hafifçe düşme gözlemledik (sırasıyla Rehabilitasyon öncesi: 30,78 mg/dl Rehabilitasyon sonrası:23,29 mg/dl; Rehabilitasyon öncesi: $79 \mathrm{U} / \mathrm{L}$, Rehabilitasyon sonrası: $71 \mathrm{U} / \mathrm{L})$.

Mitokondrial miyopati rehabilitasyonunda tedavi hedefleri mobiliteyi sürdürmek, kontraktürleri önlemek ve fonksiyonel bağımsızıı süresini mümkün olduğunca uzatmaktır. Hastaya ve ailesine, tedavinin her basamağında psikolojik destek sağlanmalıdır. Hastanın kas kuvvet kaybı ve muskulotendinöz gelişimi dikkatle izlenmelidir. Tekerlekli sandalye seviyesindeki hastalar ise skolyoz, bası yarası, obezite, kardiyak problemler vs. açısından dikkatle izlenmelidir. Daha geç evre hastalarda ise hemşirelik hizmetleri ve genel tıbbi bakım sağlanmalı, gerekli hastalarda solunum desteği verilmelidir [18].

Mitokondrial rehabilitasyonda erkenambulatuar evrede ve statik hastalara olabildiğince erken egzersiz programına başlanmalıdır. Submaksimal ve çok tekrarlı aerobik ve güçlendirme egzersizleri verilmelidir. Hastalara düşük şiddet ve sürede egzersiz ile 
başlayıp zamanla egzersiz şiddet ve süresini arttırması önerilmelidir. Hastalara "vücudunu dinle" prensibi ile ateş, kas ağrısı, kramp, ya da 12 saatten uzun açlık durumlarında egzersiz yapmamaları anlatılmalıdır [14].

Sonuç olarak, bir mitokondrial miyopati sendromu olan SANDO sendromlu hastamıza rehabilitasyon süresi boyunca tolere edebileceği ölçüde aerobik ve kuvvetlendirme egzersizi uyguladık. Hastamızın güçsüz olan bazı alt eksremite kaslarında kas gücünde artış ve yürüme kapasitesinin iyileştiğini saptadık. Ayrıca biyokimyasal incelemelerimizde bazal laktat ve CK enzim düzeylerinin hafifçe düştüğünü gözlemledik. Bu hastaları iyi monitorize ederek tolere edebileceği oranda aerobik ve güçlendirme egzersizleri ile tedavisini düzenlemek ile fonksiyonel durumlarına olumlu katkı yapmak mümkün görünmektedir. Egzersiz tipi ve yoğunluğu ile ilgili geniş popülasyonlu karşılaştırmalı çalışmalar halen intiyaç bulunmaktadır.

Çıkar ilişkisi: Yazarlar çıkar ilişkisi olmadığını beyan eder.

\section{Kaynaklar}

1. Anziska $Y$, Inan $S$. Exercise in neuromuscular disease. Semin Neurol 2014;34:542-556. https://doi. org/10.1055/s-0034-1396008

2. Kawai H, Akaike M, Yokoi K, Tamaki Y, Saito S. Mitochondrial myopathy with autosomal dominant inheritance-report of a family and review of the literature. Rinsho Shinkeigaku 1993;332:162-168.

3. Koopman WJH, Willems PHGM, Smeitink JAM. Monogenic mitochondrial disorders. N Engl J Med 2012;366:1132-1141. https://doi.org/10.1056/ NEJMra1012478

4. Angelini C. SANDO (Sensory ataxic neuropathy, Dhysarthria, Ophtalmopharesis) Genetic Neuromuscular Disorders. 2014:259-260.

5. Batur G, Ayhan FF, Alioğlu B, Okumuş M, Borman P. Pearson sendromlu bir olguda mitokondrial miyopati rehabilitasyonu. Turk Fiz Tıp Rehab Derg 2011, Ozel Sayı;341-344. https://doi.org/10.4274/tftr.14880

6. Chinnery PF, Adam MP, Ardinger $\mathrm{HH}$, et al. Mitochondrial disorders overview. Seattle 1993-2019.

7. Taivassalo T, De Stefano N, Argov Z, et al. Effects of aerobic training in patients with mitochondrial myopathies. Neurol 1998;50:1055-1060. https://doi. org/10.1212/wnl.50.4.1055
8. Siciliano G, Manca ML, Renna M, Prontera C, Mercuri $A$, Murri L. Effects of aerobic training on lactate and catecholaminergic exercise responses in mitochondrial myopathies. Neuromuscul Disord 2000;10:40-45.

9. Haller RG, Lewis SF, Cook JD, Blomqvist CG. Myophosphorylase deficiency impairs muscle oxidative metabolism. Ann Neurol 1985;17:196-199. https://doi. org/10.1002/ana.410170216

10. Lindholm H, Löfberg $M$, Somer $H$, Näveri $H$, Sovijärvi A. Abnormal blood lactate accumulation after exercise in patients with multiple mitochondrial DNA deletions and minor muscular symptoms. Clin Physiol Funct Imaging 2004;24:109-115. https://doi.org/10.1111/j.1475097X.2004.00531.X

11. Tarnopolsky $M$. Exercise testing as a diagnostic entity in mitochondrial myopathies. Mitochondrion 2004;4:529542. https://doi.org/10.1016/j.mito.2004.07.011

12. Trenell MI, Sue CM, Kemp GJ, Sachinwalla T, Thompson $\mathrm{CH}$. Aerobic exercise and muscle metabolism in patients with mitochondrial myopathy. Muscle Nerve 2006;33:524-531. https://doi.org/10.1002/mus.20484

13. Hood DA. Invited review: Contractile activity-induced mitochondrial biogenesis in skeletal muscle. J Appl Physiol 2001;90:1137-1157. https://doi.org/10.1152/ jappl.2001.90.3.1137

14.Tarnopolsky MA. Exercise as a therapeutic strategy for primary mitochondrial cytopathies. J Child Neurol 2014;29:1225-1234. https://doi. org/10.1177/0883073814538512

15. Taivassalo T, De Stefano N, Chen J, Karpati G, Arnold $\mathrm{DL}$, Argov Z. Short-term aerobic training response in chronic myopathies. Muscle Nerve 1999;22:12391243.

16. Jeppesen TD, Schwartz M, Olsen DB, et al. Aerobic training is safe and improves exercise capacity in patients with mitochondrial myopathy. Brain 2006;129:3402-3412. https://doi.org/10.1093/brain/ awl149

17. Taivassalo $T$, Matthews $P M$, De Stefano $N$, et al. Combined aerobic training and dichloroacetate improve exercise capacity and indices of aerobic metabolism in muscle cytochrome oxidase deficiency. Neurol 1996;47:529-534. https://doi.org/10.1212/wnl.47.2.529

18. Bodur H. Miyopati rehabilitasyonu. In: Oğuz H, Dursun E, Dursun N, ed. Tıbbi rehabilitasyon. 2.baskı, İstanbul: Nobel Matbaacılık 2004:695-710. 